\section{Cytogenetic characterization of Tropaeolum pentaphyllum Lam}

\author{
Kellen Regina Boldrini Tolomeotti ${ }^{1}$, Marciele Felippi ${ }^{2}$ and Joel \\ Donazzolo $^{3^{*}}$
}

\begin{abstract}
The species Tropaeolum pentaphyllum Lam. (batata-crem or crem) is of great economic and medicinal importance. For being an endangered species, the knowledge of its genetic variability is necessary. Considering the lack of cytological studies on this species, this work describes the chromosome numbers, the meiotic behavior, the meiotic index, and the viability of the pollen grains of three populations of T. pentaphyllum from Rio Grande do Sul, Brazil. The three populations presented $2 n=28$ chromosomes. Meiotic behavior was regular, with low abnormality frequency (<1\%), which culminated in IMx>90\% in the three accessions. This meiotic stability resulted in high production of viable pollen grains, which will favor the use of these accessions in selection programs for commercial purposes, conservation and sustainable use.
\end{abstract}

Key words: Crem, meiosis, chromosome number, plant breeding, plant genetic resources.

\section{INTRODUCTION}

The family Tropaeolaceae is formed by three genera, two of them, Trophaeastrum (Sparre) and Magallana (Cav.), are restricted to the region of Patagonia. The third genus, Tropaeolum, is composed of 86 species, and is found in South America and Central America (Sparre and Andersoon 1991, Fabbri and Valla 1998). In Brazil, the species Tropaeolum pentaphyllum Lam., popularly known as "batata-crem", or "crem", is more abundant in the southern states, especially in regions of higher altitudes (Kinupp et al. 2011).

Despite being considered a species of economic importance with immense potential and usefulness, it is neglected and little cultivated (Kinupp et al. 2011). The tuber is used in the preparation of antiscorbutic and depurative infusions (Mors et al. 2000), and is popularly recommended for reduction and control of cholesterol and microbial activity. In addition, leaves and flowers can be consumed (Kunkel 1984, Facciola 1998, Kinupp et al. 2011), and the plant can be used in ornamentation (Crovetto-Martínez 1981). However, the tuber is the most used part of the plant, being commercialized in natura or canned (Kinupp et al. 2011).

Propagation is carried out basically by planting tuber seed. However, it presents irregular and non-uniform sprouting, which represents reduction of productive potential, due to the need of reserving part of the production for the next planting (Kinupp et al. 2011). The use of seeds for propagation of crem has
Crop Breeding and Applied Biotechnology 18: 65-71, 2018 Brazilian Society of Plant Breeding. Printed in Brazil http://dx.doi.org/10.1590/198470332018v18n1a9

\footnotetext{
(2)
} 


\section{KRB Tolomeotti et al.}

not been the best strategy. Despite producing seeds in a reasonable quantity, the species presents dormancy and low germination index; moreover, no protocol for cultivation from seeds has been developed yet (Donazzolo et al. 2013). Thus, propagation is one of the main problems associated with the difficulty of commercial production (Otalakosky et al. 2014), which leads to the exploitation of the tubers in the native forest where it naturally occurs (Kinupp et al. 2011), hindering its genetic variability, which, according to Grossi et al. (2011), is fundamental both for the maintenance of the evolutionary process and for plant breeding.

Singh (1993) highlights meiosis as one of the sources of variability used by organisms for their adaptation to the environment, and consequently for their perpetuation through progenies. The mode of action of genes is very broad, revealing several irregularities in all phases of cell division. The meiotic behavior of an organism plays decisive role in its evolutionary stability due to the complexity of the mechanical, biochemical and genetic phenomena (Singh 1993).

Thus, cytogenetics has been widely used to study genetic variability, evolution, phylogeny, origin and taxonomy, as well as to determine strategies in breeding and conservation programs in cultivated and native species (Chen et al. 2004, Füller et al. 2015). According to Pagliarini and Pozzobon (2004), cytogenetic studies involving chromosome counting, determination of ploidy level, evaluation of meiotic behavior, and pollen viability are essential in the characterization of germplasm collections.

Thus, in cytogenetics, the determination of chromosome number is one of the most used information for the characterization of a species and for the determination of strategies to be used in plant breeding and in the establishment of conservation strategies of a species. On the other hand, the study of pollen viability allows evidencing the male reproductive potential, which contributes to the breeding planning (Souza et al. 2004).

In view of the lack of genetic information on T. pentaphyllum, the objectives of this study were to determine the chromosome numbers and to cytogenetically characterize three populations from Southern Brazil, by means of the analyses of meiotic behavior, meiotic index and pollen viability.

\section{MATERIAL AND METHODS}

Plant materials of three populations of T. pentaphyllum were analyzed. Tubers were collected in 2013 from the municipalities of Ipê ( $\mathrm{n}=58$ - cultivated area; lat $28^{\circ} 49^{\prime} 12^{\prime \prime} \mathrm{S}$, long $51^{\circ} 16^{\prime} 45^{\prime \prime} \mathrm{W}$, alt $750 \mathrm{~m}$ asl), Vacaria ( $\mathrm{n}=20$ - cultivated area; lat $28^{\circ} 30^{\prime} 44^{\prime \prime} \mathrm{S}$, long $50^{\circ} 56^{\prime} 02^{\prime \prime} \mathrm{W}$, alt $971 \mathrm{~m}$ asl), and Frederico Westphalen ( $=49$ - natural area; lat $27^{\circ} 21^{\prime} 33^{\prime \prime}$ $\mathrm{S}$, long $53^{\circ} 23^{\prime} 40^{\prime \prime} \mathrm{W}$, alt $522 \mathrm{~m}$ asl), Southern Brazil. Each tuber was considered to be from a different plant, although it is not possible to genetically define if they are distinct, considering the asexual reproduction (Kinupp et al. 2011) of the species. However, there is no possibility of gene flow among populations considering their distance $(>50 \mathrm{~km})$.

After collection, tubers were cultivated in the years of 2013, 2014 and 2015 in an experimental area of the Federal University of Technology - Paraná (UTFPR), located in Campus de Dois Vizinhos - state of Paraná, Brazil (lat 25 $42^{\prime} 52^{\prime \prime}$ $\mathrm{S}$, long $53^{\circ} 03^{\prime} 94^{\prime \prime} \mathrm{W}$, alt $530 \mathrm{~m}$ asl), as described in Donazzolo et al. (2013) and Otalakosky et al. (2014). The climate is classified as Cfa, according to Köppen, with annual average temperature of $19.3^{\circ} \mathrm{C}$ (Alvares et al. 2013).

During the flowering phenophase in 2015, 50 pre-anthesis floral buds from 10 different plants were collected from each population and stored in Carnoy (ethanol-acetic acid 3:1) for $24 \mathrm{~h}$, transferred to $70 \%$ alcohol, and then stored under refrigeration $\left(6\right.$ to $10^{\circ} \mathrm{C}$ ) until analysis. Analyses were carried out in the Cytogenetic Laboratory of the Central West State University (UNICENTRO), Campus de Guarapuava - Paraná. Initially, the plant material was dissected for microsporocytes extraction, and were prepared using the squashing method, and stained with $0.5 \%$ propionic carmine, according to Guerra (2002).

The material was observed using an Olympus X31TM microscope with up to $1000 \mathrm{X}$ magnification. Chromosomes were counted from the diakinesis phase, and could be observed in metaphase I, anaphase I, and prophase II. At least 20 randomized cells of each origin were analyzed to determine chromosome number, according to Dahmer et al (2008) and Simioni and Valle (2011).

For the analysis of the meiotic behavior, all meiosis phases, from the diakinesis, were considered. At least 500 microsporocytes were counted per population ( $n=10$ plants). The most significant meiotic abnormalities were photographed 
using an image capture Olympus X31TM microscope, with $40 \mathrm{X}$ objective lens. Images were captured by the software Pixelview station v5. 23 TV, and scanned by the Corel Photo-Paint X6.

The meiotic index (IMx) was calculated according to Love (1951): IMx = number of normal tetrads/total number of tetrads $x 100$. Pollen mother cells (PMC) with four microspores were considered normal tetrads, and those with numbers of microspores different from four (dyads, triads, polyades) were considered abnormal (Corrêa et al. 2005).

For the counting and analysis of the pollen grains, at least 1000 (50 of 20 glass microscope slides) cells per population were used and stained with $1 \%$ Lugol. Viability was determined by the coloring ability of the pollen grains; the ones with dark tonality and with a lot of genetic material were considered as viable, and those with clear tonality and with little or no genetic material were considered as unviable (Guerra 2002).

Data were subjected to descriptive statistics, and frequencies were subjected to association analysis in a contingency table with chi-square test, using the Past software (Hammer et al. 2001).

\section{RESULTS AND DISCUSSION}

The three populations of T. pentaphyllum analyzed in this study have $2 n=28$ chromosomes (Figure 1a), with different types of chromosome associations in diakinesis, varying from bi to tetravalent (Figure $1 \mathrm{~b}$ ). Based on the literature, the determination of chromosome number for species of the genus Tropaeolum does not contemplate T. pentaphyllum, which makes the present results extremely important, since it complements information on the species. Among the chromosome number already reported for the genus, $2 n=24,26,28,30,42,48$ and 52 should be cited (Sugiura 1925, Darlington and Ammal 1945, Gibbs et al. 1978, Johns and Towers 1981, Sparre and Andersson 1991, Alfredo et al. 2003), with basic number $\mathrm{x}=7$.

In the genus, other species with $2 n=28$ are found, such as T. majus and T. peltophorum (Sugiura 1925). However, chromosome studies for the genus Tropaeolum have shown contradictory results. The presence of high ploidy levels, hybridization and sexual an asexual reproduction, are the likely factors that contribute to a blurred picture (Alfredo et al. 2003). No studies have been found in the literature on the chromosomal variation of T. pentaphyllum. The present work suggests that the species is a polyploidy $2 n=4 x=28$ chromosomes.

In angiosperms, between 30 and 35\% to $80 \%$ of the species are considered polyploid (Soltis and Soltis 1999), 70\% of which have undergone one or more polyploidization processes (Masterson 1994). According to Stebbins (1971), polyploidy,

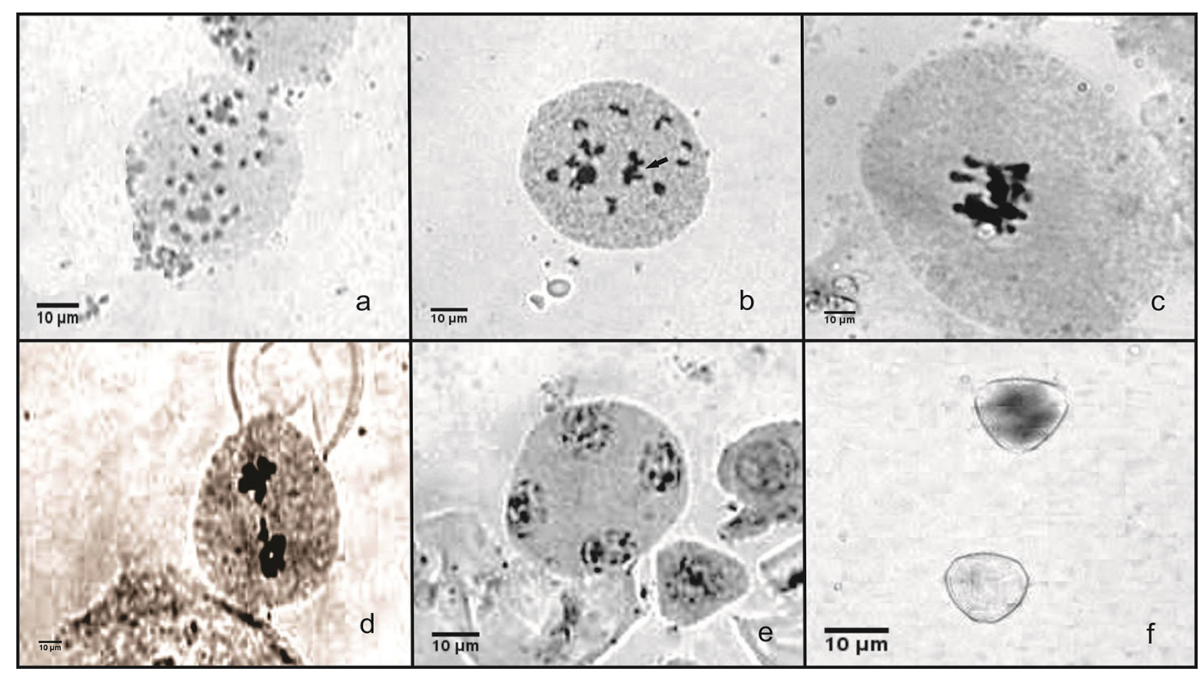

Figure 1. Aspects of the microsporogenesis of Tropaeolum pentaphyllum Lam.: a) Prophase II with 28 chromosomes; b) diakinesis with bivalent and tetravalent associations (arrow); c) metaphase with precocious chromosome migration to the pole; d) anaphase I with laggard chromosome; e) normal telophase II and f) viable and unviable pollen grains. (400x). 
i.e., the existence of more than two genomes in the same nucleus, is the most important cytogenetic alteration in the speciation and evolution of native and cultivated plants.

In the family Tropaeolaceae, hybridization between species has already been reported (Sparre and Andersson 1991). According to Johns and Towers (1981), T. tuberosum ssp. tuberosum is an allopolyploid, i.e., it is the result of the crossing between T. tuberosum ssp. silvestre and other species of the genus Tropaeolum, possibly $T$. cochabamba $(2 n=26)$.

From the three populations of T. pentaphyllum, chromosome associations were observed in some cells. Among them, the tetravalent associations stood out (Figure 1b). According to Stebbins (1947), the low frequency of multivalents is an argument used in defense of a segmental allopolyploid. In this type of association, the genomes are not identical, and are the result of the hybridization of narrowly diploid species ( $A A A^{\prime} A^{\prime}$ ), followed by duplication of the chromosome number, resulting in the pairing between the identical chromosomes, consequently forming bivalent, and some multivalent associations. Conversely, Sybenga $(1994,1996)$ considers that the pairing affinity, and therefore the homology between chromosomes is not a reliable indicator, since many autopolyploid may present chromosome pairing in both multivalent and tetravalent associations, but in low frequency and polysomic inheritance. In the case of T. penthaphyllum, due to the few reports on the genus, a genomic study involving the in situ hybridization is necessary, in order to contemplate information on the origin of the studied populations and their evolution.

Meiotic abnormalities resulting from irregular segregation of chromosomes were observed in some meiosis phases in the populations from Vacaria and Ipê (Table 1). Precocious chromosome migration to the poles in metaphase I (Figure 1c), laggard chromosomes in anaphase I (Figure 1d), and micronuclei in telophase I and prophase II were the most frequent abnormalities. Significant association between the observed abnormalities and the population for $\mathrm{Ml}$ (metaphase I), Al (anaphase I), and TI (Telophase I) were observed; no association was observed for abnormalities in PII (prophase II). However, the total abnormality frequency was lower than $1 \%$ in populations from Vacaria and Ipê, and no meiotic irregularities were observed for the population from Frederico Westphalen, which resulted in a non-association between abnormality frequency and population (Table 1).

Despite the statistical dissimilarity verified between some meiosis phases, this difference was not enough to imply significant alterations in meiotic behavior. Even with irregular segregation, at the end of the process, chromosomes reached the telophase nucleus, concluding the division with $100 \%$ normal tetrads. In any case, further studies involving other populations should be carried out in order to evaluate if environmental issues have any effect on meiotic behavior.

Meiosis is characterized by the occurrence of a series of mechanical and biochemical events, which results in the formation of four haploid microspores. Such sequence of events involves pairing homologous chromosomes, occurrence of genetic exchange, formation of chiasmas, and chromosome segregation, all of them controlled by a large number of genes (Golubovskaya 1979). In this way, the normal and harmonious course of meiosis guarantees the viability of the gamete (Pagliarini 2000). In this study, the meiotic process was totally controlled for the population from Frederico Westphalen.

Recent studies in native species of the state of Rio Grande do Sul show irregularities in meiotic behavior similar to that of crem, but with a predominance of regularity and high pollen viability in lemon grass (Elionurus muticus) (Füller et al. 2015), cherry tree accessions (Eugenia involucrata) (Guerra et al. 2016), and Paspalum notatum tetraploidized plants (Krycki et al. 2016).

Table 1. Microsporogenesis considering 2n, number of microsporocytes (M.A.) analyzed, percentage of abnormalities (\% A), abnormality frequency (A.F.) and meiotic index (IMx) in three populations of Tropaeolum pentaphyllum, collected in Rio Grande do Sul

\begin{tabular}{|c|c|c|c|c|c|c|c|c|c|c|c|}
\hline Population & $2 n$ & N. M.A. & & & & $\% A$ & & & & A.F. & IMx \\
\hline & & & MI & Al & $\mathrm{TI}$ & PII & MII & All & TII & & \\
\hline Vacaria & 28 & 1360 & $5.7^{*}$ & $0 *$ & $0^{*}$ & 2.2 & 0 & 0 & 0 & 0.59 & 100 \\
\hline $\begin{array}{l}\text { Frederico West- } \\
\text { phalen }\end{array}$ & 28 & 440 & 0 & 0 & 0 & 0 & 0 & 0 & 0 & 0.00 & 100 \\
\hline Total & 28 & 2649 & 1.4 & 1.3 & 1.0 & 1.7 & 0 & 0 & 0 & 0.61 & 100 \\
\hline
\end{tabular}

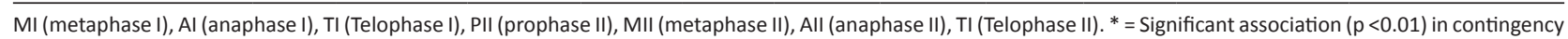
analysis with chi-square test. 
Table 2. Estimate of pollen viability in three populations of Tropaeolum pentaphyllum collected in Rio Grande do Sul

\begin{tabular}{lccc}
\hline Population & N. pollens analyzed & \multicolumn{2}{c}{ Pollen viability } \\
\cline { 3 - 4 } & & 1432 & \% Unviable \\
\hline Vacaria & 1575 & 0.14 & 99.86 \\
Ipê & 1275 & 0.13 & 99.87 \\
Frederico Westphalen & 4282 & 0.47 & 99.53 \\
Total & & 0.24 & 99.76 \\
\hline
\end{tabular}

According to Pagliarini (2000), irregular chromosome segregation is the most common meiotic abnormality in both cultivated and native species, being characterized by the presence of chromosomes in precocious chromosome ascension and laggard choromosome. These abnormalities have been reported in Zeas mays (Ricci et al. 2007), Saccharum officinarum (Pagliarini et al. 1990), Avena sativa (Baptista-Giacomelli et al. 2000), in species of the genus Paspalum (Pagliarini et al. 2001; Dahmer et al. 2008), in genus Capsicum L. (Souza et al. 2012), and in Brachiaria (Boldrini et al. 2009, Boldrini et al. 2011, Mendes-Bonato et al. 2006).

Irregular chromosome segregation can be caused by several genetic and environmental factors. The presence of univalent in diakinesis and precocious chromosome migration to the poles in metaphase I may be a result of the precocious chiasma terminalization, causing the migration of precocious chromosomes to the poles, since chiasmas are generally responsible for the maintenance of the bivalents for the perfect segregation occurrence (Singh 1993, Pagliarini 2000), or due to the presence of synaptic or disynaptic genes in prophase I (Koduru and Rao 1981). In Capsicum baccatum accession, small chromosome alterations can occur in the process of domestication and improvement (Souza et al. 2012).

Regardless of the factors involved in segregation, the result of this meiotic behavior is always the same, with the presence of precocious chromosomes migration to the poles in metaphase I, or of laggard chromosomes in anaphase I. However, the presence of the latter is also related to the formation of micronuclei, and this irregular chromosome segregation occurs since they do not bind to the spindle fibers, forming micronuclei (Risso-Pascotto et al. 2003). When micronuclei are formed in telophase I, they may persist during meiosis II, and even reach the tetrad phase or be reincorporated into the equatorial plate of the second division, and then they are no longer visualized (Adamowski et al. 2000, Mendes-Bonatto et al. 2001, Risso-Pascotto et al. 2003). Such behavior was observed in the populations from Vacaria and Ipê. However, irregular segregation was not enough to hinder the production of normal tetrads (Figure 1e).

Considering that the meiotic index (IMx) is a complement to the meiotic analysis and an indicator of regularity, according to Love (1951), results found in this work (Table 1) demonstrate meiotic stability. The author states that the IMx explores post-meiotic products, such as tetrads, triads, dyads, monads and polyads, and usually, during meiosis, greater numbers of normal tetrads are expected. Thus, genotypes with meiotic indices below $90 \%$ describe a species with low meiotic stability, suggesting a tendency to the occurrence of abnormalities during the gametogenesis process.

Specimens with meiotic index above $90 \%$, as observed in "crem" $(100 \%)$, are considered as of high meiotic stability, which is not a problem for hybridization in breeding programs or for conservation purposes. The meiotic stability observed in T. penthaphyllum resulted in the high percentage of viable pollen grains (Table 2) (Figure 1f), with values above $99 \%$ of pollen viability, probably reflecting the development conditions of the male reproductive structure of the flower, which contributes to its productive capacity and seed production. According to Fabbri and Valla (1998), 52\% of $T$. penthaphyllum flowers produce seeds; however these flowers depend on cross-pollination, since only $2.5 \%$ of protected flowers produce fruit.

\section{CONCLUSION}

The three populations of $T$. penthaphyllum from the southern of Brazil presented $2 n=4 x=28$ chromosomes. In this study, the meiotic behavior was regular, resulting in high IMx (100\%), and a high percentage of viability of viable pollen grains (above 99\%).

The populations from Vacaria, Ipê and Frederico Westphalen have reproductive potential, which enables their sexual reproduction, and assists the conservation process in natural habitat and the use of $T$. penthaphyllum in plant breeding programs. 


\section{REFERENCES}

Adamowski EV, Pagliarini MS and Batista LAR (2000) Chromosome number and microsporogenesis in Paspalum maritimum (Caespitosa Group; Gramineae). Brazilian Archives of Biology and Technology 43: 1-6.

Alfredo G, Dueñas RO, Cabrerra CN and Hermann M (2003) Mashua (Tropaeolum tuberosum Ruíz \& Pav.). Promoting the conservation and use of underutilized and neglected crops. 25. International Potato Center, Lima/International Plant Genetic Resources Institute, Rome, Italy, 55p.

Alvares CA, Stape JL, Sentelhas PC, Gonçalves JLM and Sparovek G (2013) Köppen's climate classification map for Brazil. Meteorol Zeitschrift 22: 711-728.

Baptista-Giacomelli FR, Pagliarini MS and Almeida JL (2000) Meiotic behavior in several Brazilian oat cultivars (Avena sativa L.). Cytologia 65: 371-375.

Boldrini KR, Adamowski EV, Message H, Calisto V, Pagliarini MS and Valle CB (2011) Meiotic behavior as a selection tool in the breeding of Brachiaria humidicola (Poaceae). Euphytica 182: 317-324.

Boldrini KR, Pagliarini MS and Valle CB (2009) Meiotic behavior of a nonaploid accession endorses $\mathrm{x}=6$ for Brachiaria humidicola (Poaceae). Genetic and Molecular Research 8: 1444-1450.

Chen Q, Lynch D, Platt HW, Li HY, Shi Y, Li HJ, Beasley D, Rakosy-Tican L and Theme R (2004) Interspecific crossability and cytogenetic analysis of sexual progenie of mexican wild diploid 1 EBN species Solanum pinnatisectum and S.cardiophyllum. American Journal of Potato Research 81: 159-169.

Corrêa MGS, Viegas J, Silva JB, Avila PFV, Busato GR and Lmes JS (2005) Meiose e viabilidade polínica na família Araceae. Acta Botanica Brasilica 19: 295-303.

Crovetto-Martínez R (1981) Plantas utilizadas en medicina en el NO de corrientes. Fundación Miguel Lillo, Tucuman, 135p. (Miscelanea № 69)

Dahmer N, Schifino-Wittmann MT, Dall'agnol M and Castro B (2008) Cytogenetic data for Paspalum notatum Flügge aceessions. Scientia Agricola 65: 381-388.

Darlington CD and Ammal J (1945) Chromosome atlas of cultivated plants. George Allen \& Unwin Ltd, London, 261p.

Donazzolo J, Felippi M, Ribeiro RJ, Silva MD and Dalla DHE (2013) Avaliação da brotação de tubérculos-semente de Tropaeolum pentaphyllum Lam. cultivadas no campo. Cadernos de Agroecologia 8: 1-5.

Fabbri LT and Valla JJ (1998) Aspectos de la biología reproductiva de Tropaeolum pentaphyllum (Tropaeolaceae). Darwiniana 36: 51-58.

Facciola S (1998) Cornucopia II - a Source Book of Edible Plants. Kampong Publications, Vista, 713p.

Füller TN, Guerra D, Schifino-Wittmann MT, Tessele C, De Barros IBI and Barbosa Neto JF (2015) Genetic and cytogenetic structure of wild lemon grass (Elinonurus muticus) populations. Crop Breeding and
Applied Biotechnology 15: 272-277.

Gibbs PE, Marshall D and Brunton D (1978) Studies on the cytology of Oxalis tuberosa and Tropaeolum tuberosum. Royal Botanical Garden 37: 215-220.

Golubovskaya IN (1979) Genetic control of meiosis. International Review of Cytology 58: 247-290.

Grossi JA, Godoy SM, Macedo CR, Paula GBN, Romagnolo MB and Risso-Pascotto C (2011) Comportamento meiótico durante a microsporogênese em espécies da família Meliaceae. Arquivos de Ciências Veterinárias e Zoologia da UNIPAR 14: 51-56.

Guerra D, De Souza PVD, Schwarz SF, Schifino-Wittmann MT, Werlang CA and Veit PA (2016) Genetic and cytological diversity in cherry tree accessions (Eugenia involucrata DC) in Rio Grande do Sul. Crop Breeding and Applied Biotechnology 16: 219-225.

Guerra M and Souza MJ (2002) Como observar cromossomos: Um guia de técnicas em citogenética vegetal, animal e humana. Funpec, Ribeirão Preto, 132p.

Hammer $\varnothing$, Harper DAT and Ryan PD (2001) PAST: Paleontological statistics software package for education and data analysis. Palaeontologia Electronica 4: 1-9.

Johns T and Towers GHN (1981) Isothiocyanates and thioureas in enzyme hydrolysates of Tropaeolum tuberosum. Phytochemistry 20: 26872689.

Kinupp VF, Lisbôa GN and Barros IBI (2011) Tropaeolum pentaphyllum, Batata-crem. In Coradin L, Siminski LC and Reis A (eds) Espécies nativas da flora brasileira de valor econômico atual ou potencial: plantas para o futuro - Região Sul. Ministério do Meio Ambiente, Brasília, p. 243-250.

Koduru PKR and Rao MK (1981) Cytogenetics of synaptic mutants in higher plants. Theoretical and Applied Genetics 59: 197-214.

Krycki KC, Simioni C and Dall'Agnol M (2016) Cytoembryological evaluation, meiotic behavior and pollen viability of Paspalum notatum tetraploidized plants. Crop Breending and Applied Biotechonolgy 16: 282-288.

Kunkel G (1984) Plants for human consumption. Koeltz Scientific Books, Koenigstein, 393p.

Love RM (1951) Varietal differences in meiotic chromosomes behavior of Brazilian wheats. Agronomy Journal 43: 72-76.

Masterson J (1994) Stomatal size in fossil plants: evidence for polyploidy in majority of angiosperms. Science 264: 421-424.

Mendes-Bonato AB, Pagliarini MS, Valle CB and Penteado MIO (2001) A severe case of chromosome stickiness in pollen mother cells of Brachiaria brizantha (Hochst) Staf (Gramineae) Cytologia 66: 287-291.

Mendes-Bonato AB, Risso-Pascotto C, Pagliarini MS and Valle CB (2006) Chromosome number and meiotic behaviour in Brachiaria jubata (Gramineae). Journal of Genetics 85: 83-86. 
Mors WB, Rizzini CT and Pereira N (2000) A medicinal plants of Brazil. Reference Publications, Michigan, 501p.

Otalakoski J, Donazzolo J and Felippi M (2014) Avaliação da produção de tubérculos de Tropaeolum pentaphyllum Lam. (Tropaeolaceae) sob cultivo orgânico. Cadernos de Agroecologia 9: 1-5.

Pagliarini MS (2000) Meiotic behavior of economically important plant species: The relantionship between fertility and male sterility. Genetics and Molecular Biology 23: 997-1002.

Pagliarini MS, Carraro LR, Freitas PM, Adamowski EV, Batista LAR and Valls JFM (2001) Cytogenetic characterization of Brazilian Paspalum acessions. Hereditas 135: 27-34.

Pagliarini MS and Pozzobon MT (2004) Meiose vegetal: um enfoque para a caracterização de germoplasma. EMBRAPA Recursos Genéticos e Biotecnologia, Brasília, 89p. (Documentos, 154)

Pagliarini MS, Sila SP and Mollinari R (1990) Análise meiótica em cultivares de cana-de-açúcar. Archives of Biology and Technology 33: 283-293.

Ricci GCL, Silva N, Pagliarini MS and Scapim CA (2007) Microsporogenesis in inbred line of popcorn (Zea mays L.) Genetic and Molecular Research 6: 1013-1018.

Risso-Pascotto C, Mendes-Bonato AB, Pagliarini MS, Bione NCP and Valle CB (2003) Comportamento citológico atípico durante a microsporogênese em Brachiaria ruziziensis e $B$. decumbens. Embrapa Gado de Corte, Campo Grande, 33p. (Boletim de Pesquisa e Desenvolvimento, 16).

Simioni C and Valle CB (2011) Meiotic analysis in induced tetraploids of Brachiaria decumbens. Stapf. Crop Breeding and Applied
Biotechnology 11: 43-49.

Singh RJ (1993) Plant cytogenetics. CRC Press, Boca Raton, 391p.

Soltis DE and Soltis P (1999) Polyploidy: recurrent formation and genome evolution. Trends in Ecology \& Evolution 14: 348-352.

Souza MM, Pereira TNS, Viana AP, Pereira MG and Amaral Junior AT (2004) Flower receptivity and fruit characteristics associated to time of pollination in yellow passion fruit. Scientia Horticulturae 01: 373-385.

Souza MM, Pereira TNS, Sudre CP and Rodrigues R (2012) Meiotic irregularities in Capsicum L. species. Crop Breeding and Applied Biotechnology 12: 138-144.

Sparre B and Andersson L (1991) A taxonomic revision of the Tropaeolaceae. Council for Nordic Publications in Botany, Copenhagen, 108p.

Stebbins GL (1947) Types of polyploids: their classification and significance. Advances in Genetics 1: 403-429.

Stebbins GL (1971) Chromosomal evolution in higher plants. AddisonWesley, Reading, 216p.

Sugiura T (1925) Meiosis in Tropaeolum majus L. The Botanical Magazine, Tokyo, 39p.

Sybenga J (1994) Preferential pairing estimates from multivalent frequencies in tetraploids. Genome 37: 1045-1055.

Sybenga J (1996) Chromosome pairing affinity and quadrivalent formation in polyploids: do segmental allopolyploids exist? Genome 39: 11761184. 